\title{
KEBUGARAN JASMANI DAN INDEK MASA TUBUH MAHASISWA PROGRAM STUDI IKORA FIK UNY
}

\author{
Oleh: Eka Swasta Budayati \\ Dosen Jurusan Pendidikan Kesehatan dan Rekreasi FIK UNY
}

Abstrak

Penelitian ini bertujuan untuk: (1) menganalisis keadaan kebugaran jasmani mahasiswa Ikora FIK UNY, dan (2) untuk menganalisis indek masa tubuh (IMT) mahasiswa Ikora FIK UNY. Penelitian ini diharapkan bermanfaat sebagai masukan dan bahan pertimbangan bagi lembaga terkait dalam rangka membuat program kegiatan kampus.

Desain yang digunakan dalam penelitian ini adalah penelitian survei, dengan teknik tes. Subjek penelitian ini adalah mahasiswa S1 Ikora. Sampel yang digunakan adalah mahasiswa prodi Ikora angkatan tahun 2009 semester II, sebanyak 55 mahasiswa, yang terdiri atas 52 laki-laki dan 3 perempuan. Untuk mengetahui kebugaran jasmani, digunakan instrumen tes lari keliling lapangan selama 12 menit dari tes Cooper, sedangkan untuk mengetahui IMT diukur dengan tes tinggi badan (TB) dalam satuam meter dan Berat Badan dalam satuan kilogram. Teknik analisis data dengan analisis diskriptif dengan persentase.

Peneltian ini menyimpulkan bahwa: Tingkat kebugaran jasmani mahasiswa Ikora FIK UNY adalah sebagai berikut: (1) $7(12,72 \%)$ mahasiswa termasuk dalam katagori Sangat Buruk, (2) 11 (20,00 \%) mahasiswa termasuk dalam katagori Buruk, (3) $22(40,0 \%)$ mahasiswa termasuk dalam katagori Sedang, (4) $8(14,547 \%)$ mahasiswa termasuk dalam katagori Baik, (5) 7 (12,72\%) mahasiswa termasuk dalam katagori Baik Sekali, (6) $0(0,00 \%)$ mahasiswa termasuk dalam katagori Istimewa, Di samping itu IMT Mahasiswa Ikora FIK UNY adalah sebagai berikut: (1) $5(9,09 \%)$ mahasiswa termasuk dalam katagori Kurus Tingkat Ringan, (2) 1 $(1,82 \%)$ mahasiswa termasuk dalam katagori Kurus Tingkat Berat, (3) 43 (78,18 $\%$ mahasiswa termasuk dalam katagori normal, (4) 4 (7,277 \%) mahasiswa termasuk dalam katagori Gemuk Tingkat Ringan, dan (5) 2 (3,64 \%) siswa termasuk dalam katagori Gemuk Tingkat Berat.

Kata Kunci: kesegaran mahasiswa, berat badan ideal

Tuntutan akan kebugaran jasmani setiap orang berbeda. Perbedaan ini biasanya dipengaruhi oleh jenis perkerjaan dari tiap-tiap orang. ABRI dituntut memiliki tingkat 
kebugaran jasmani yang lebih tinggi daripada pegawai ataupun mahasiswa, karena ABRI harus bekerja lebih berat dan lebih lama ketika sedang bertugas, misalnya untuk berperang atau untuk berjaga-jaga, sedangkan bagi mahasiswa kebugaran jasmani dipergunakan untuk belajar, kuliah atau kegiatan yang mendukung perkuliahan. Oleh karena itu sebaiknya setiap mahasiswa hendaknya memiliki kebugaran jasmani yang baik guna mendukung, mempermudah, dan memperlancar perkuliahannya.

Terlebih bagi mahasiswa Prodi Ikora yang hampir setiap hari harus mengikuti perkuliahan praktik maupun teori, selain harus memiliki bakat dan minat yang baik, juga harus memiliki kebugaran jasmani yang memadai, dan juga harus memiliki kesehatan yang prima. Kesehatan dan kebugaran jasmani diperlukan mahasiswa untuk mempertinggi kemampuan belajar dan menyelesaikan tugas-tugas lainnya.

Selain kebugaran jasmani yang baik, seorang mahasiswa hendaknya juga harus memiliki IMT yang ideal, karena dengan IMT yang ideal dimungkinkan seseorang akan mencapai derajat kesehatan yang baik. IMT dipakai sebagai salah satu indikator untuk mempresentasikan setatus gizi dan merupakan suatu indeks yang responsif dan sensitif terhadap perubahan keadaan gizi dan produktivitas kerja (Atmarita \& Fasli Jalal,1991; Husaini, 1996).

Derajat kesehatan dan kebugaran jasmani dipengaruhi oleh berbagai ubahan, yang terkadang sulit dianalisis. Faktor latihan atau aktivitas fisik jika dilakukan dengan terprogram, teratur, dan terukur merupakan faktor dominan yang memengaruhi kebugaran maupun kesehatan seseorang. Pola hidup termasuk pola makan dengan tercukupi gizi serta pengaturan istirahat yang baik merupakan faktor lain yang tidak kalah pentingnya untuk menciptakan kesehatan maupun kebugaran jasmani. Lingkungan hidup yang higienis juga sangat mempengaruhi kondisi kesehatan seseorang. Faktor faktor tersebut saling memengaruhi satu dengan yang lain. Jika faktor faktor tersebut tidak saling mendukung, mustahil dapat tercipta derajat kesehatan maupun kebugaran yang baik.

Rutinitas mahasiswa untuk melakukan olahraga yang teratur adalah tanggung jawab pribadi. Artinya, lembaga FIK tidak melakukan pemantauan secara khusus, karena mahasiswa dianggap sudah paham akan kebutuhan dan tuntutan fisik yang harus dimiliki sebagai mahasiswa. Demikian pula kebiasaan mengatur makan (diet makanan) seharusnya mahasiswa sudah bisa menjalaninya dengan baik. Namun demikian, tidak semua mahasiswa dapat menjalani pola hidup yang sedemikain teratur, karena berbagai kendala, seperti banyaknya tugas-tugas kuliah, atau mungkin ada sebagian yang sudah bekerja, sehingga kesulitan mengatur waktu untuk menjalani olahraga yang teratur. Meski demikian tidak bisa dipungkiri, jika mahasiswa serius mengikuti kuliah-kuliah praktik, tidak jarang mahasiswa mengalami kelelahan, sehingga untuk menjaga kebugaran tidak perlu latihan tambahan. Data yang menggambarkan tingkat kebugaran jasmani maupun IMT mahasiswa Ikora FIK-UNY belum ada, karena itu penelitian ini dimaksudkan untuk mengkaji secara mendalam, tentang keadaan kebugaran jasmani dan IMT mahasiswa Ikora FIK UNY.

MEDIKORA Vol. VII, No. 1, April 2011: 65 - 76 
Berdasarkan uraian pada latar belakang masalah tersebut, permasalahan dalam penelitian ini dapat dirumuskan sebagai berikut: (1) Bagaimanakah keadaan kebugaran jasmani Mahasiswa IKORA? (2) Bagaimanakah IMT mahasiswa IKORA?

\section{KAJIAN PUSTAKA}

Menurut Sumosardjuno (1989) kebugaran jasmani adalah kemampuan seseorang untuk menunaikan tugas sehari--hari dengan mudah, tanpa merasa lelah yang berlebihan, serta mempunyai cadangan tenaga untuk menikmati waktu senggangnya dan untuk keperluan mendadak. Suharjana (2004: 5) menyatakan bahwa kebugaran jasmani adalah kemampuan seseorang untuk dapat melakukan aktivitas sehari hari sesuai pekerjaannya tanpa timbul kelelahan yang berlebihan, sehingga masih dapat menikmati waktu luang. Getchell (1979) menyatakan bahwa kebugaran jasmani adalah kemampuan jantung, pembuluh darah, dan otot untuk berfungsi dengan efisien dan optimal.

Dari beberapa pendapat di atas dapat disimpulkan bahwa kebugaran jasmani adalah kualitas seseorang untuk melakukan aktivitas sesuai pekerjaannya secara optimal tanpa menimbulkan problem kesehatan dan kelelahan berlebihan. Dalam penelitian ini yang dimaksud kebugaran jasmani adalah kemampuan tubuh untuk bekerja secara efisien tanpa timbul kelelahan yang berarti yang ditandai oleh kemampuan mengkonsumsi oksigen secara maksimum melalui tes daya tahan kardiorespirasi, yaitu melalui tes lari 2,4 km atau tes lari selama 12 menit

Seseorang dapat dikatakan memiliki status kebugaran jasmani yang baik, kalau orang tersebut memenuhi derajat kebugaran yang baik menurut parameter tertentu. Salah satu parameter yang digunakan untuk menentukan derajat kebugaran jasmani seseorang adalah dengan tes kardiorespirasi. Tes kardiorespirasi merupakan tes penggunaan oksigen oleh tubuh selama kerja maksimum. Oksigen merupakan unsur kimia yang penting bagi pembakaran dalam tubuh, semakin tinggi pengambilan oksigen oleh tubuh berarti semakin banyak cadangan kehidupan seseorang. Oleh karena itu pengukuran sistem kardiorespirasi menjadi penting. Seperti dikatakan oleh Kuntaraf (1982: 156) volume oksigen yang tinggi akan menyebabkan peredaran darah lancar, jantung sehat, dan tekanan darah normal. Atas dasar alasan tersebut, yang dimaksud kebugaran jasmani dalam penelitian ini cukup diwakili oleh pengukuran kemampuan daya tahan kardiorespirasi atau sering disebut kebugaran umum.

Selain memiliki derajat kebugaran jasmani yang baik, indikator lain yang perlu diketahui adalah derajat kesehatan seseorang, derajat kesehatan seseorang dapat dilihat dari berat badan ideal. Seseorang dikatakan mempunyai ukuran ideal apabila bentuk tubuhnya tidak terlalu kurus maupun terlalu gemuk dan terlihat serasi antara berat dan tinggi badan. Agar tubuh seseorang ideal, lemak di dalam tubuhnya harus dalam keadaan normal. Lemak memang harus ada di dalam tubuh, tetapi jangan sampai kekurangan atau berlebihan. 
Lemak merupakan zat yang dibutuhkan tubuh, namun jika kadar pada tubuh berlebihan sering tidak diinginkan lagi. Lemak dalam tubuh berperan sebagai cadangan energi, penyimpanan vitamin yang larut dalam lemak, dan bertugas melindungi organorgan tubuh dari benturan-benturan. Lemak diperlukan tubuh dalam jumlah yang cukup, yaitu minimal $3 \%$ dari berat badan, baik pada pria maupun wanita. Lemak dalam tubuh yang jumlahnya melebihi $3 \%$ dari berat badan disebut timbunan lemak. Timbunan lemak tubuh disimpan pada bagian-bagian tubuh tertentu, misalnya di bawah kulit, dalam jaringan pelindung perut, jaringan ikat sekitar ginjal, di lapisan permukaan jantung.

Timbunan lemak normal dalam tubuh bagi pria dewasa adalah $15-20 \%$ dari berat badan, dan 20-25\% dari berat badan bagi wanita. Proporsi ini akan meningkat sesuai dengan bertambahnya umur. Pada wanita dewasa tua masih dianggap normal apabila timbunan lemak tubuh sampai $30 \%$ dari berat badan. Apabila timbunan lemak tubuh pada wanita dewasa sudah melebihi $30 \%$ dari berat badan ideal, dikatagorikan kegemukan, sedangkan pada pria dewasa dikatakan kegemukan apabila timbunan lemaknya sudah melebihi $27 \%$ dari berat badan ideal. Seseorang yang kelebihan berat badan akan sering merasa kehabisan napas, badan terasa berat, sering kepanasan atau gerah, sering sakit pada bagian pingang, pinggul, paha, dan lutut. Hal ini merupakan suatu peringatan bahwa seseorang harus sadar dan harus melakukan pengaturan makanan serta latihan fisik yang cukup dan sesuai agar tetap sehat dan bugar.

IMT (Body Mass Index) merupakan penentuan berat badan sehat yang sekarang banyak juga dipakai dan berlaku untuk orang dewasa yang berumur di atas 18 tahun. IMT tubuh ditentukan berdasarkan berat badan $(\mathrm{kg})$ dibagi kuadrat tinggi badan (meter). Adapun rumus lengkapnya dicontohkan oleh Emma (1997: 11) sebagai berikut: IMT = BB (kg)/ $\mathrm{TB}^{2}(\mathrm{~m})$. IMT adalah konversi dari hasil pengukuran anthropometric tinggi badan dan berat badan. IMT hingga kini dipakai secara meluas untuk menentukan status gizi seseorang. Menurut Husaini (1996) hasil survey di negara-negara maju maupun berkembang IMT ternyata merupakan indeks yang responsife, sensitif terhadap perubahan keadaan gizi.

Berat badan seseorang dipengaruhi oleh tinggi badan. Selama proporsi dipertahankan badan untuk seorang yang bertubuh tinggi lebih berat daripada seseorang berperawakan pendek. Dari perbandingan hasil pengukuran anthropometric BB dan TB, status gizi seseorang dapat diketahui apakah tergolong terlalu kurus atau sebaliknya. Menurut Husaini (1996) IMT orang dewasa $>25,0$ dikategorikan gemuk, antara 18,5-25,0 dikategorikan normal, antara 17,0-18,4 dikategorikan kurang gizi I, antara 16,0-16,9 dikategorikan kurang gizi II, dan 16,0 dikategorikan kurang gizi III.

Olahraga atau aktivitas jasmani membutuhkan energi yang cukup, dalam keseharian total keluaran energi seseorang adalah jumlah dari energi yang dikeluarkan dalam keadaan isirahat atau disebut BMR (Basal Metabolic Rate), ditambah dengan energi yang dikeluarkan untuk pencernaan makanan dan absorbsi zat-zat gizi atau SDA (Specific Dynamic Action), ditambah lagi energi yang dikeluarkan untuk bekerja atau aktivitas olahraga. Dalam

MEDIIKORA Vol. VII, No. 1, April 2011: 65 - 76 
terminologi yang lebih spesifik, badan terdiri atas jaringan aktif atau disebut sebagai lean body mass dan fat mass sebagai deposit energi utama di dalam tubuh. Jadi berat badan sama dengan lean body mass + fat mass. Kaitanya dengan kebugaran jasmani, akibat diet makanan, latihan olahraga atau kombinasi keduanya dapat mengubah komposisi tubuh, sehingga berpengaruh terhadap proporsi relatif berat tulang, otot, dan lemak. Jaringan tanpa lemak (lean tissue) lebih aktif daripada jaringan berlemak (fat tissue), sehingga orang yang gemuk mempunyai BMR per kilogram berat badan lebih rendah daripada orang yang kurus. Jadi yang beraktivitas tinggi dan mampu berkerja keras adalah orang yang tidak berbadan terlalu gemuk dan tidak pula terlalu kurus.

Pendidikan di Prodi Ikora FIK UNY antara lain mengutamakan partisipasi semua mahasiswa dan mengupayakan pendidikan itu membentuk kebiasaan hidup sehat dan aktif di sepanjang hayat. Berkenaan dengan usaha untuk mencapai kualitas hidup sehat tersebut, kurikulum pendidikan, maupun berbagai kegiatan kokurikuler diarahkan untuk membentuk mahasiswa mencapai kebugaran total atau total fitness. Kebugaran secara total mencakup empat aspek, yaitu; kebugaran fisik, emosional, sosial, dan intelektual (Howlley, 1992). Namun demkian pencapaian berbagai aspek yang berkaitan dengan gaya hidup sehat tersebut sepenuhnya bergantung pada mahasiswa yang bersangkutan untuk dapat memanfatkan fasilitas, kesempatan ataupun tenaga ahli yang ada di lembaga pendidikan tersebut.

Penelitian yang dilakukan oleh Suharjana (2001) pada siswa sekolah dasar (SD) di DIY menyimpulkan bahwa $62,4 \%$ siswa SD di DIY status kebugaran jasmaninya kurang. Sementara jika dilihat dari status gizinya menunjukkan $19,6 \%$ berstatus gemuk, sedangkan yang berstatus gizi kurang ada 39,2 \% dan yang berada dalam status normal hanya 41,28 $\%$. Peneitian yang dilakukan Sarwono (2001) dengan subjek penelitian mahasiswa Jurusan POK FKIP UNS menemukan bahwa dari 80 subjek, katagori kesegaran jasmani: Jelek ada 18,7 \%, Kurang 27,5 \%, Sedang 32,5 \%, Baik $20 \%$, dan Baik Sekali 1,3 \%, sedangkan status gizi: Gemuk ada $13 \%$, Normal $80 \%$, Kurang Gizi I 12,5 \%, Kurang Gizi II 7,5 \%, dan Kurang Gizi III 2,5 \%. Penelitian Wahyu Tri Harjanto (2007: 6) dengan judul "Status Kondisi Fisik Pemain Persiba Bantul pada Kompetisi Tahun 2007”. Populasi yang digunakan adalah seluruh pemain Persiba Bantul, dengan jumlah atlet sebanyak 24 atlet yang seluruhnya dijadikan sebagai sampel penelitian. Metode penelitian yang digunakan survey dengan teknik tes dan pengukuran dari Harsuki. Hasil penelitian menunjukkan bahwa, secara umum dapat diketahui bahwa pemain Persiba Bantul memiliki kemampuan yang berada pada rentang kurang dan sedang dalam melakukan tiap item tes. Penelitian yang dilakukan oleh Suharjana (2007) dengan judul "Profil Kebugaran Fisik Pelajar SLTA di Kabupaten Kulon Progo Daerah Istimewa Yogyakarta", dengan sampel sebanyak 410 pelajar SLTA Negeri dan Swasta di Kulonprogo, dengan instrumen tes lari keliling lapangan berjarak 2,4 km dari tes Cooper menyimpulkan bahwa kebugaran fisik pelajar SLTA di Kabupaten Kulonprogo sebagian besar dalam kategori "Kurang Segar", yaitu mencapai $232(56.6 \%)$ siswa. 


\section{METODE PENELITIAN}

A. Desain Penelitian

Desain yang digunakan dalam penelitian ini adalah penelitian survey, dengan teknik tes (Zainudin,1988).

B. Populasi dan sampel Penelitian

Populasi dalam penelitian ini adalah mahasiswa S1 Ikora. Sampel yang digunakan adalah mahasiswa Prodi Ikora angkatan tahun 2009 semester II, sebanyak 55 mahasiswa, yang terdiri atas 52 laki-laki dan 3 perempuan. Teknik yang digunakan untuk mengambil sampel adalah dengan teknik random sampling (Nasir, 2003). Langkah yang dilakukan adalah memilih mahasiswa tahun angkatan kuliah. Semua mahasiswa angkatan terpilih dijadikan sebagai sampel. Hasil pemilihan sampel jatuh pada mahasiswa angkatan tahun 2009.

C. Instrumen Penelitian

Untuk mengetahui kebugaran jasmani digunakan instrumen tes lari keliling lapangan selama 12 menit dari tes Cooper (Cooper, 1980: 89). Untuk mengetahui IMT diukur dengan tes TB (m) dan BB (kg)

D. Teknik Analisis Data

Data statistik dianalisis dengan analisis deskriptif persentase. Untuk mengetahui status kebugaran fisik dilakukan dengan cara mencocokkan jarak tempuh $(\mathrm{km})$ dari tes lari 12 menit yang dimiliki mahasiswa dengan tabel kebugaran kardiorespirasi seperti pada tabel 1 berikut ini:

Tabel 1. Kategori Kebugaran Kardiorespirasi berdasarkan Tes Jalan/Lari dalam 12 Menit (Jarak $(\mathrm{Km})$ yang dicapai dalam 12 Menit

\begin{tabular}{|l|l|l|}
\hline \multirow{2}{*}{ Tingkat Kebugaran Jasmani } & \multicolumn{2}{c|}{ Jarak Tempuh (Km) } \\
\cline { 2 - 3 } & \multicolumn{1}{|c|}{ Laki-Laki } & \multicolumn{1}{c|}{ Perempuan } \\
\hline Sangat Buruk (SBR) & $<2,09$ & $<1,6$ \\
\hline Buruk (BR) & $2,09-2,20$ & $1,61-1,89$ \\
\hline Sedang (S) & $2,21-2,51$ & $1,90-2,07$ \\
\hline Baik (B) & $2,52-2,76$ & $2,08-2,30$ \\
\hline Baik Sekali (BS) & $2,77-2,99$ & $3.31-2,43$ \\
\hline Istimewa (I) & $>33,00$ & $>2,44$ \\
\hline
\end{tabular}

Sumber: (Cooper, 1980: 89)

Untuk mengetahui IMT dilakukan dengan cara membagi BB dengan TB. Adapun rumusnya adalah $\mathrm{IMT}=\mathrm{BB}(\mathrm{kg}) / \mathrm{TB}^{2}(\mathrm{~m})$. Hasil perhitungan tersebut kemudian dicocokkan dengan tabel 2 kategori ambang batas IMT untuk Indonesia (Depkes, 1994: 4). 
Tabel 2. Pedoman Praktis Pemantauan Status Gizi Orang Dewasa

\begin{tabular}{|l|l|l|}
\hline & \multicolumn{1}{|c|}{ Kategori } & \multicolumn{1}{c|}{ IMT } \\
\hline \multirow{2}{*}{ Kurus } & Kekuarangan berat badan tingkat berat & $<17,0$ \\
\cline { 2 - 3 } & Kekuarangan berat badan tingkat ringan & $17,0-18,5$ \\
\hline \multirow{2}{*}{ Normal } & Berat Badan Normal/ideal & $>18,5-25,0$ \\
\hline \multirow{2}{*}{ Gemuk } & Kelebihan berat badan tingkat ringan & $>25,0-27,0$ \\
\cline { 2 - 3 } & Kelebihan berat badan tingkat berat & $>27,0$ \\
\hline
\end{tabular}

Sumber: (Depkes, 1994: 4)

\section{HASIL PENELITIAN DAN PEMBAHASAN}

\section{A. Hasil Penelitian}

Data dalam penelitian ini diperoleh dari hasil pengukuran terhadap 2 variabel, yaitu tingkat kebugaran jasmani dan IMT. Hasil penelitian yang dimaksud adalah sebagai berikut:

1. Tingkat Kebugaran Jasmani Mahasiswa

Penelitian ini menemukan bahwa tingkat kebugaran jasmani Mahasiswa Ikora FIK UNY secara keseluruhan baik laki laki maupun perempuan yang berjumlah 55 mahasiswa dapat dilihat pada tabel 3 di bawah ini:

Tabel 3.

\begin{tabular}{|c|l|c|c|}
\hline No. & Kategori Keb. Jas. & Jumlah & Persentase \\
\hline 1. & Sangat Buruk & 7 & 12.72 \\
\hline 2. & Buruk & 11 & 20.00 \\
\hline 3. & Sedang & 22 & 40.00 \\
\hline 4. & Baik & 8 & 14.54 \\
\hline 5. & Sangat Baik & 7 & 12.72 \\
\hline 6. & Istimewa & 0 & 0.00 \\
\hline & Jumlah & 55 & 100 \\
\hline
\end{tabular}

Berdasarkan tabel 3 hasil penelitian tersebut di atas, dapat dijelaskan bahwa tingkat kebugaran jasmani mahasiswa Ikora FIK UNY secara keseluruhan dari jumlah sampel 55 orang adalah sebagai berikut:

a. Tujuh $(12.72 \%)$ mahasiswa termasuk dalam katagori Sangat Buruk (SBR).

b. Sebelas $(20.00 \%)$ mahasiswa termasuk dalam katagori Buruk (BR).

c. Dua puluh dua $(40.0 \%)$ mahasiswa termasuk dalam katagori Sedang (S).

d. Delapan (14.547 \%) mahasiswa termasuk dalam katagori Baik (B). 
e. Tujuh (12.72\%) mahasiswa termasuk dalam katagori Baik Sekali (BS).

f. Nol $(0.00 \%)$ mahasiswa termasuk dalam katagori Istimewa (I).

2. Indeks Masa Tubuh Mahasiswa

Penelitian ini juga menemukan bahwa IMT Mahasiswa Ikora FIK UNY secara keseluruhan baik laki laki maupun perempuan yang berjumlah 55 mahasiswa dapat dilihat pada tabel 4 di bawah ini:

Tabel 4. Indeks Masa Tubuh Mahasiswa

\begin{tabular}{|c|l|c|c|}
\hline No. & \multicolumn{1}{|c|}{ Kategori } & Jumlah & Persentase \\
\hline 1. & Kurus Tingkat Ringan & 5 & 9.09 \\
\hline 2. & Kurus Tingkat Berat & 1 & 1.82 \\
\hline 3. & Normal & 43 & 78.18 \\
\hline 4. & Gemuk Tingkat Ringan & 4 & 7.27 \\
\hline 5. & Gemuk Tingkat Berat & 2 & 3.64 \\
\hline 6. & Jumlah & 55 & 100 \\
\hline
\end{tabular}

Berdasarkan tabel 4 hasil penelitian tersebut di atas, IMT mahasiswa Ikora FIK UNY dapat dijelaskan bahwa secara keseluruhan dari jumlah sampel 55 orang adalah sebagai berikut:

a. Lima $(9.09 \%)$ mahasiswa termasuk dalam kategori Kurus Tingkat Ringan (KTR).

b. Satu $(1.82 \%)$ mahasiswa termasuk dalam kategori Kurus Tingkat Berat (KTB).

c. Empat puluh tiga $(78.18 \%)$ mahasiswa termasuk dalam kategori normal $(\mathrm{N})$.

d. Empat $(7.277 \%)$ mahasiswa termasuk dalam kategori Gemuk Tingkat Ringan (GTR).

e. Dua $(3.64 \%)$ mahasiswa termasuk dalam kategori Gemuk Tingkat Berat (GTB).

\section{B. Pembahasan}

Hasil penelitian tersebut menunjukkan bahwa tingkat kebugaran jasmani mahasiswa lebih dari $70 \%$ masuk dalam katagori antara buruk sampai sedang. Sementara yang masuk dalam katgori baik tidak mencapai $30 \%$. Kondisi ini sebenarnya sungguh memprihatinkan, mengingat mahasiswa adalah sekelompok masyarakat cendekia yang masih giat-giatnya menuntut ilmu. Hal ini menggambarkan mahasiswa Prodi Ikora FIK UNY kurang aktif melakukan latihan olahraga. Kebugaran jasmani penting bagi semua orang untuk mendukung aktivitas kerja dalam kehidupan sehari hari, termasuk kegiatan belajar dan menyelesaikan studi. Seperti dikatakan oleh Sharkey (2003: 30) bahwa untuk mendapatkan kebugaran yang baik seseorang harus berpola hidup sehat, yaitu: (1) mengatur makanan, (2) mengatur istirahat, dan (3) melakukan aktivitas (berolahraga). 
Dengan berolahraga seseorang akan mencapai tingkat kebugaran jasmani yang baik. Jika kebugaran jasmani seseorang baik, harapannya orang tersebut juga akan memiliki derajat kesehatan yang baik pula.

Jika dilihat dari IMT, ternyata lebih dari $75 \%$ IMT mahasiswa dalam katagori normal. Hasil ini menggabarkan bahwa berat badan para mahasiswa mayoritas ideal. Hasil ini menunjukkan bahwa kecukupan gizi para mahasiswa cukup memadai. Dengan demikian secara fisiologis kebutuhan energi para mahasiswa untuk menopang kegiatan sehari-hari tercukupi. Untuk melakukan aktivitas sehari-hari manusia memerlukan energi. Energi adalah kemampuan untuk melakukan kerja, sedangkan kerja dapat diartikan dengan daya yang dilakukan pada jarak tertentu. Energi yang digunakan untuk bergerak berasal dari makanan, oleh karena itu jika mahasiswa kecukupan gizinya, kebutuhan energi dalam kesehariannya juga tercukupi.

Sekilas dilihat dari kedua hasil penelitian ini, di satu sisi kebugaran jasmani mahasiswa dalam katagori buruk, sementara disisi lain IMT mahasiswa dalam katagori normal. Hasil penelitan ini menunjukkan pada suatu kondisi yang menggambarkan tidak adanya hubungan linier antara buruknya status kebugaran jasmani dan kondisi ideal berat badan mahasiswa. Dengan mengatur pola makan, seseorang bisa mencapai berat badan ideal, akan tetapi tidak serta merta kebugaran jasmani seseorang juga dalam status baik. Untuk mencapai kebugaran yang baik selain mengatur menu makanan, seseorang juga harus berolahraga dengan teratur dan terprogram. Olahraga yang baik adalah olahraga yang sesuai pilihannya. Seorang mahasiswa FIK UNY bisa memilih berbagai cabang olahraga yang tersedia di bawah koordinasi universitas melalui kegiatan ekstrakurikuler. Sebaiknya olahraga tersebut dilakukan seminggu tiga kali. Jika olahraga tersebut dilakukan dengan benar niscaya akan mengakibatkan terjadinya perubahan, diantarannya keadaan anatomi, fisiologi, biokimia, dan psikologi, yang pada gilirannya akan meningkatkan kebugaran jasmani pelakunya.

Seperti dikatakan oleh Bompa (1994) agar program latihan dapat mengakibatkan perubahan, latihan harus diprogram sesuai dengan prinsip-prinsip latihan yang benar. Prinsip-prinsip latihan adalah meliputi FITT (frequecy, intensity, time \& type). Pinsip-prinsip tersebut dapat dijelaskan sebagai berikut:

1. Intensitas latihan

Intensitas latihan merupakan komponen latihan yang sangat penting untuk dikaitkan dengan komponen kualitas latihan yang dilakukan dalam kurun waktu yang diberikan. Untuk mengembangkan daya tahan paru dan jantung intensitas latihan sering menggunakan denyut jantung (HR). Bompa (1994) membuat zona latihan daya tahan paru jantung sebagai berikut: 
Tabel 5. Intensitas Latihan

\begin{tabular}{|c|c|c|}
\hline Daerah & Jenis Intensitas & Denyut Jantung per Menit \\
\hline 1 & Rendah & $120-150$ \\
\hline 2 & Menengah & $150-170$ \\
\hline 3 & Tinggi & $170-185$ \\
\hline 4 & Maksimal & Lebih 185 \\
\hline
\end{tabular}

2. Frekuensi Latihan

Frekuensi menunjuk pada jumlah latihan per minggu. Secara umum, frekuensi latihan lebih banyak, dengan program latihan lebih lama akan mempunyai pengaruh lebih baik terhadap kebugaran paru jantung. Frekuensi latihan yang baik untuk menjaga kesehatan 3 kali per minggu, sedang atlet bisa lebih dari itu.

Latihan dengan frekuensi tinggi membuat tubuh tidak cukup waktu untuk pemulihan. Tubuh biasanya membutuhkan waktu istirahat lebih dari 24 jam. Untuk individu yang tidak terlatih membutuhkan waktu 48 jam untuk pemulihan. Semakin bertambah usia semakin lama waktu yang dibutuhkan untuk pemulihan.

3. Durasi Latihan (Time)

Durasi menunjukkan pada lama waktu yang digunakan untuk latihan. Jarak menunjuk pada panjangnya langkah, atau pedal, atau kayuhan yang dapat ditempuh. Kalori menunjuk pada jumlah energi yang digunakan selama latihan. Untuk mendapatkan kebugaran yang lebih besar, latihan lebih lama dari 30 menit, hal ini mungkin karena proporsi metabolisme lemak terus naik pada 30 menit pertama latihan. Karena itu untuk mendapatkan kebugaran, kontrol berat badan dan durasi latihan harus antara 30-60 menit.

4. Bentuk Latihan (Type)

Untuk meningkatkan kebugaran jasmani yang baik banyak bentuk latihan yang dapat dipilih, seperti: (1) countinuous training, (2) interval training, dan (3) circuit training.

Continuous training atau latihan kontinu atau sering disebut latihan terus menerus adalah latihan yang dilakukan tanpa jeda istirahat, dilakukan secara terus menerus tanpa berhenti. Waktu yang digunakan untuk latihan kontinu relatif lama, antara 3060 menit. Latihan kontinu menggunakan intensitas $60-80 \%$ dari HR.Max. Latihan yang baik 3-5 hari per minggu. Ada bermacam-macam bentuk latihan kontinu, seperti: jogging, jalan kaki, lari di atas treadmill, bersepeda statis, bersepeda, atau berenang.

Interval training atau latihan berselang adalah latihan yang bercirikan adanya interval kerja diselingi interval istirahat (recovery). Bentuknya bisa interval running (lari interval) atau interval swimming (berenang interval). Latihan interval biasanya mengunakan intensitas tinggi, yaitu $80-90 \%$ dari kemampuan makasimal. Waktu (durasi) yang digunakan antara 2-5 menit. Lama istirahat antara 2-8 menit. 
Perbandingan latihan dengan istirahat adadah 1:1 atau 1:2. Repetisi (ulangan) 3-12 kali.

Circuit training dirancang selain untuk mengembangkan kapasitas paru, juga untuk mengembangkan kekuatan otot. Sirkuit training merupakan bentuk latihan yang terdiri atas beberapa pos (station) latihan yang dilakukan secara berurutan dari pos satu sampai pos terakhir. Jumlah pos antara 8-16. Istirahat dilakukan pada jeda antara pos satu dengan lainnya.

\section{KESIMPULAN DAN SARAN-SARAN}

\section{A. Kesimpulan}

1. Tingkat kebugaran jasmani mahasiswa Ikora FIK UNY adalah sebagai berikut: (1) 7 $(12,72 \%)$ mahasiswa termasuk dalam kategori Sangat Buruk, (2) $11(20,00 \%)$ mahasiswa termasuk dalam kategori Buruk, (3) 22 (40,0 \%) mahasiswa termasuk dalam kategori Sedang, (4) 8 (14,547 \%) mahasiswa termasuk dalam kategori Baik, (5) $7(12,72 \%)$ mahasiswa termasuk dalam kategori Baik Sekali, (6) 0 (0,00\%) mahasiswa termasuk dalam kategori Istimewa

2. IMT mahasiswa Ikora FIK UNY adalah sebagai berikut: (1) $5(9,09 \%)$ mahasiswa termasuk dalam kategori Kurus Tingkat Ringan, (2) 1 (1,82\%) mahasiswa termasuk dalam kategori Kurus Tingkat Berat, (3) 43 (78,18 \%) mahasiswa termasuk dalam kategori normal, (4) $4(7,27 \%)$ mahasiswa termasuk dalam kategori Gemuk Tingkat Ringan, (5) 2 (3,64 \%) mahasiswa termasuk dalam kategori Gemuk Tingkat Berat.

\section{B. Saran-Saran}

Dari hasil penelitian ini, peneliti mengemukakan beberapa saran, di antaranya:

1. Untuk memperoleh kebugaran jasmani yang bagus, hendaknya dilakukan aktivitas jasmani secara teratur, terukur, dan terprogram.

2. Bagi mahasiswa yang kebugaran jasmaninya masih masuk dalam kategori kurang dan sangat kurang, hendaknya guru memberikan motivasi pada anak untuk aktif beraktivitas dan mengatur pola makan.

\section{DAFTAR PUSTAKA}

Atmarita \& Fasli Jalal (1991). "Perhitungan, Penggunan dan Interpretasi Berbagai Indek Anthropometri dalam Penilaian Status Gizi". Dengan Baku Rujukan WHO NCHS. Dalam Gizi Indonesia. Journal of The Indonesian Nutrition Association. Jakarta: Persagi. Vol .XVI. No.1-2.

Bompa, T.O. (1994). Theory and Methodology of Training: The Key to Athletics Performance. Dubuque: Kendal/ Hunt Publishing Company. 
Cooper, K. (1980). The Aerobics Way. New York: Bantam Books, Inc.

Emma S. W (1997). Cara Aman dan Efektif Menuunkan Berat Badan. Jakarta: Gramedia Pustaka Utama

Getchell, B. (1979). Physical Fitness A Way of Life. New York: John Wiley and Sons. Inc.

Husaini (1996). "Energi dan Berat Badan Usia Lanjut". Dalam Gizi Indonesia. Journal of The Indonesian Nutrition Association. Jakarta: Persagi. Vol. XVI. No.1-2.

Howley, E.T. dan Franks, B.DD (1992). Health Fitness. Instructor's Handbook. South Australia: Kinetics Publisher.Inc.

Kuntaraf, J. dan Kuntaraf, K.L. (1982). O1abraga Sumber Kesehatan. (Alih Terjemahan Eddy E. Saerang). Jakarta: Publishing House.

Sarwono (2001). "Kebugaran Jasmani Mahasiswa Hubungannya dengan Indek Masa Tubuh dan Kadar Haemoglobin.” (Studi Pada Jurusan POK FKIP UNS). Jurnal Penelitian Pendidikan Paedagogia. FKIP-UNS.

Sumosardjuno, S. (1989). Petunjuk Praktis Kesehatan O1abraga. Jakarta: Pustaka Karya Grafita Utama.

Sharkey, B.J. (2003). Fitness And Health. (Terjemahan Kebugaran dan Kesehatan Eri Desmarini Nasution). Jakarta: PT Raja Grafindo Persada.

Suharjana (2001). "Status Gizi dan Kesegaran Jasmani Siswa Sekolah Dasar se DIY". Laporan Penelitian. Yogyakarta: FIK UNY.

............ (2004). Kebugaran Jasmani. Buku Pegangan Kuliah Mahasiswa FIK UNY. Yogyakarta: FIK UNY.

Zainudin M. (1988). Metodologi Penelitian. Surabaya: Fakultas Pascasarjana Universitas Airlangga. 